\title{
Conodonts, Calcichordates and the Origin of Vertebrates
}

\author{
Jan Bergström ${ }^{1}$, Wilfried W. Naumann ${ }^{2}$, Jens Viehweg $^{2}$ \& Mónica Martí-Mus ${ }^{3}$
}

With 6 Figures

\begin{abstract}
Interpretation of early deuterostome evolution and relationships has been hampered by the lack of soft-part preservation in most groups. In addition, a recently revealed upside-down life orientation of vertebrates (the only real notoneuralians) compared to other bilateral animals has been misinterpreted as evidence for a unique body design in all deuterostomes, misleading any search for relatives. Regarding echinoderms, the variety of body plans is confusing. The interpretation of some fossils with echinoderm-type calcite skeletons as "calcichordate" ancestors of chordates, however, involves a hypothetical reconstruction of an unusual body plan and a long series of hypothetical transitions. The number of necessary steps is much lower if cephalochordates (amphioxus or lancelet) are derived directly from hemichordate enteropneusts. "Sensation interpretations" of fossils (Yunnanozoon, Cathaymyrus) from Burgess Shale type deposits have added further confusion. Soft-part preservation of conodont animals, with $V$-shaped myomeres and a notochord, shows that they were segmented chordates, while probable eyes and teeth suggest that they were already on the vertebrate side.
\end{abstract}

Key words: Deuterostomes, protostomes, amphioxus, conodont animals, hemichordates, calcichordates, notoneuralians.

\section{Zusammenfassung}

Die Interpretation früher Deuterostomia hinsichtlich ihrer Evolution und verwandtschaftlichen Beziehungen ist in den meisten Gruppen durch den Mangel an Weichkörpererhaltung sehr erschwert. Die kürzlich entdeckte Tatsache, daß Vertebraten, d. h. die einzigen echten Notoneuralia, im Gegensatz zu anderen bilateral symmetrischen Organismen eine mit ihrer ursprünglichen Oberseite nach unten gerichtete Lebensstellung einnehmen, hat zu der irrtümlichen Ansicht geführt, daß alle Deuterostomia über einen im Tierreich einzigartigen Bauplan verfügen. Diese Interpretation brachte naturgemäß jede Suche nach Verwandtschaftsverhältnissen auf Abwege.

Hinsichtlich der Echinodermata ist die bauplanmäßige Variation in der Tat verwirrend. Die Interpretation einiger Fossilien mit Echinodermen-ähnlichen Kalzitskeletten als "calcichordate“ Vorfahren der Chordata setzt jedoch die hypothetische Rekonstruktion eines ungewöhnlichen Bauplans sowie eine lange Serie hypothetischer Übergänge voraus. Die Anzahl der notwendigen Schritte ist sehr viel geringer, wenn Cephalochordaten (Amphioxus oder das Lanzettfischchen) von hemichordaten Enteropneusta abgeleitet werden. Zusätzliche Verwirrung hat es durch sensationelle Interpretationen von Fossilien, wie Yunnanozoon und Cathaymyrus aus Burgess-Schiefer-artigen Ablagerungen gegeben. Weichkörpererhaltung von Conodontentieren, die V-förmige Myomere sowie einen Notochord besitzen, zeigen, da $\beta$ es sich um segmentierte Chordata handelte, während sie die Präsenz möglicher Augenstrukturen und Zähne bereits auf die Seite der Vertebraten stellt.

Schlüsselwörter: Deuterostomia, Protostomia, Amphioxus, Conodonten-Tiere, Hemichordata, Calcichordata, Notoneuralia.

\section{Introduction}

Attempts to trace the invertebrate origin of vertebrates usually recognise the other chordate groups, the cephalochordates and urochordates (tunicates), as the closest relatives. Some Palaeozoic skeletonised fossils, the calcichordates or carpoids, also play a role in the discussion. The latter are classically considered as echinoderms, but in a series of publications by Jefferies and others they are placed on the vertebrate lineage. The history of research will not be considered here, since it has recently been thoroughly reviewed by Gee (1996).

The different phyla and subphyla of deuterostomes are notably different from one another in

\footnotetext{
1 Department of Palaeozoology, Swedish Museum of Natural History, P.O. Box 50007, 10405 Stockholm, Sweden. E-mail <jan.bergstrom@nrm.se>

${ }_{2}$ Institut für Zoologie, Talstraße 33, D-04103 Leipzig, Germany. E-mail <naumann@rz.uni-leipzig.de>

3 Department of Palaeontology, Uppsala University, Norbyvägen 22, S-752 36 Uppsala, Sweden. E-mail<Monica.Marti@pal.uu.se>

Received August 1997, accepted Juny 1998
} 
basic designs. It is therefore no wonder that there is great disagreement between interpretations, with attempts to derive deuterostomes from many places between the base and the top of the protostome (gastroneuralian) tree.

We should note that St. Hilaire (1822) explained the differences by suggesting that vertebrates rolled over to an upside-down posture compared to protostomes (gastroneuralians). The classical argument for this suggestion was that the vertebrate blood circulates in a direction opposite to that in protostomes. A rolling-over would mean that there is a fundamental identity in direction, the difference being only apparent.

Recently, the upside-down explanation has received unexpected support from the field of developmental science by the discovery that corresponding dorso-ventralling genes in insects and vertebrates act on opposite sides of the body in the two groups (Arendt \& Nübler-Jung 1994; Nübler-Jung \& Arendt 1994; Holley et al. 1995; De Robertis \& Sasai 1996). This opens completely new perspectives for understanding the origination and evolution of deuterostomes as well as for comparative morphology.

It should be noted that the situation in deuterostomes other than vertebrates has not yet been elucidated. Therefore the molecular arguments do not tell us where in the evolutionary tree rolling-over occurred. This is discussed below.

We recognize that the ultimate solution of the question of vertebrate origins should be consistent with the basic designs and phylogenetic positions of "calcichordates", urochordates, and cephalochordates.

\section{Ciliary bands and deuterostome relationships}

Any data matrix that yields correct information reveals a disordered distribution of morphological characters among phyla; notably there is no clear separation between protostomes and deuterostomes. If a matrix shows a more ordered separation, there is reason to question its quality. In the data matrix of Nielsen (1987: Fig. 33), some data appear to reflect the author's expectations rather than observation (see Bergström 1997). For instance, hemichordates are said to have their central nervous system on the dorsal side, which is hardly the case - at least not with regard to the main longitudinal trunk where it is in fact ventral. Nielsen correctly noted the difference between upstream and downstream food collecting in pelagic larvae. From this he specu- lated that the distribution of the two feeding methods marks two major branches of animals. As a result, some tentaculate phyla were added to the deuterostomes. However, few features, if any, unite tentaculates and deuterostomes except for the upstream collecting system. It should be noted that an upstream collecting system is typical for groups in which the second larval ciliary band (metatroch) develops into the adult ciliated tentacles. Therefore it seems more likely that this unique similarity is caused by convergent functional adaptation.

Nielsen (1987) thus interprets the downstream and upstream collecting systems as key characters for two major lineages of bilateral animals without seeing a functional link between them. Furthermore, his model offers no explanation to the molecular phylogenetic trees which do not coincide with his tree. It also causes striking contradictions in the interpretation of classical morphological characters (for instance by interpreting ctenophorans as deuterostomes), and fails to explain the existence of orthologous genes in bilaterians.

It should be noted that protostome and deuterostome ciliary patterns are not as clearcut as the names may imply. Nielsen (1987: 217) refers to a polychaete worm (Owenia) which is similar to deuterostomes in having monociliate cells in the prototroch and metatroch. Deuterostomes may have a protostome-type telotroch with compound cilia (Nielsen 1987: Fig. 8).

We note (1) that ciliary bands always develop from the ectoderm adjoining the hypothetically slit-like gastropore, (2) that ciliary bands serve filter-feeding and swimming, (3) that primary larvae grow to a maximum size (delimited by ciliary band arrangement, relative length of the larva, and inflation of it, see Emlet 1994), and (4) that selection controls the maximum size.

In the trochophora larva, the ciliary band germ gives rise to the epitroch (prototroch) and hypotroch (mesotroch). Functional fusion results in a double band structure, the downstream collecting system, which transports food particles to the mouth when the two constituent ciliary bands beat in opposite directions. Efficiency was further increased by fusion of cilia and by the development of a telotroch.

There are alternatives to this trend, for instance the development of a simpler upstream collecting system. Adult bivalves with ciliary feeding have shifted to deuterostome-type upstream-collecting (Nielsen 1987: 225). In this case, however, the shift has not been taken over 


\section{trochophore}
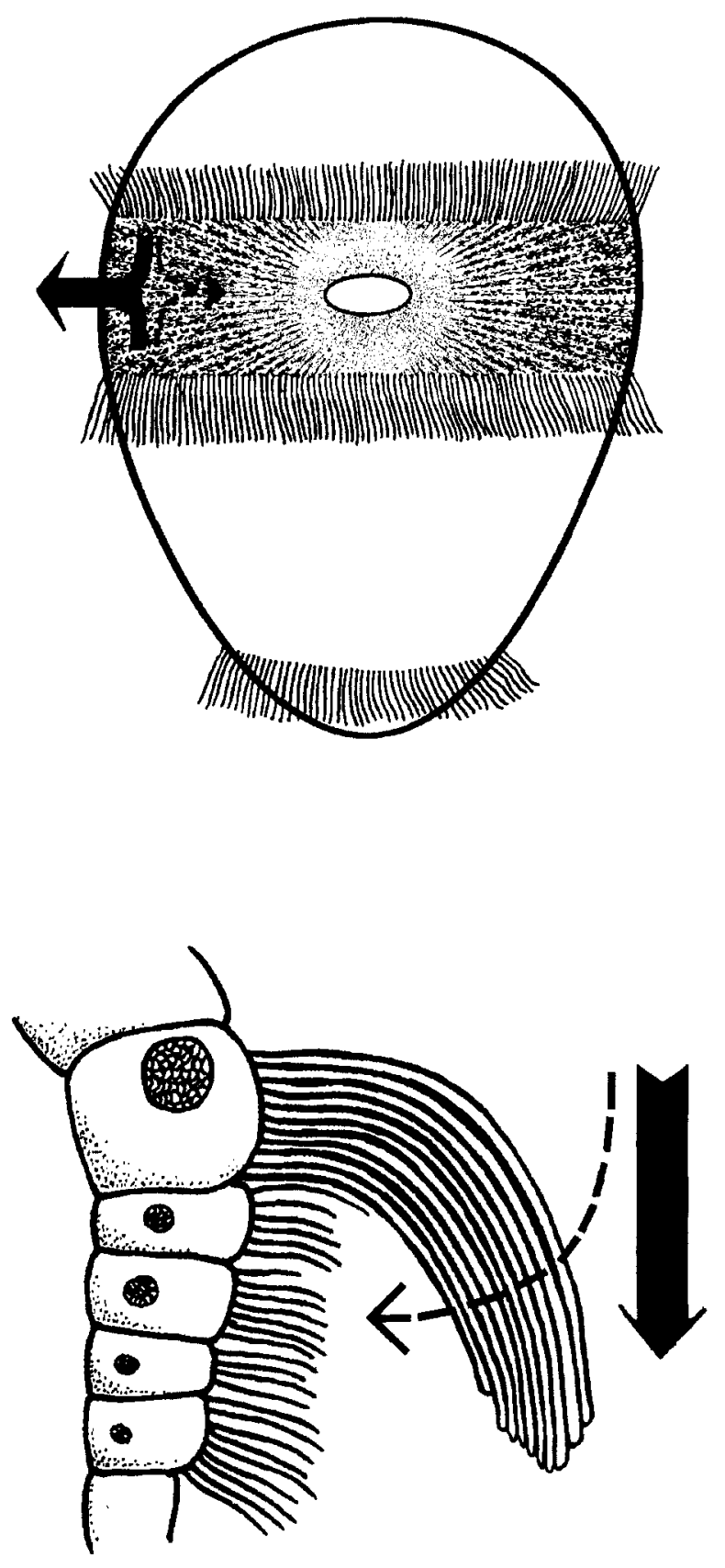

downstream
collecting
system tornaria
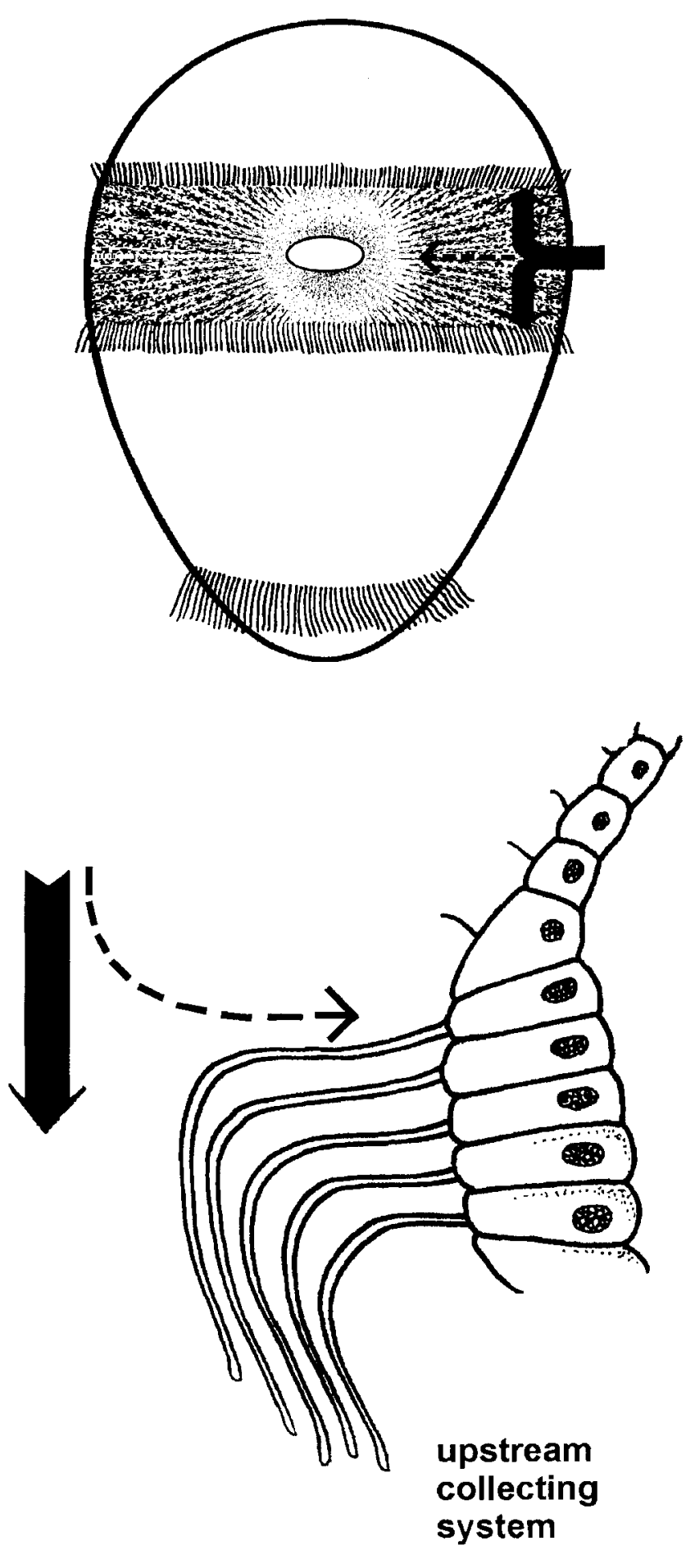

Fig. 1. Downstream and upstream collecting systems in marine larvae. In a typical trochophore larva, food parlicles collect on the lee side of cilia. Cells are typically multiciliate, and cilia (long in drawing) compound. In a tornaria and echinoderm larva food particles are instead strained off on the "windward" side of the cilia. Cells are typically monociliate, and cilia (long in drawing) separate. In both cases the food particles are transported to the mouth by fine cilia (short in drawing) in the oral field. Water current solid black arrows, strained food particles stippled 
by the larvae. Other alternatives include band folding (several times among echinoderms, even with formation of "band islands"), as well as additional rings similar to the telotroch (up to five rings in the doliolaria larva in sea cucumbers, see for instance Nielsen 1987: Fig. 31). Both systems could become enlarged in the equatorial plane, for instance by the downstream system in the veliger larva and the upstream system in adult phoronids and pterobranchs. Additionally, the upstream collecting system became improved by the invention of pharyngeal slits in primeval deuterostomes, which allowed a more efficient separation of water and food particles before they enter the gut.

It is thus clear that there were several parallel attempts to overcome the size limitation of the downstream collecting system. Despite its simple structure, or perhaps because of it, the upstream collecting system functions in larger larvae (for instance of Luidia) as well as in ciliary-feeding adults (bivalves, phoronids etc). Therefore primary larvae with different adaptational approaches do not necessarily represent separate monophyletic lineages but can be derived from a shared basic design.

Ciliary bands are underlain by nerve fibres. Garstang (1894) therefore suggested that the neural tube in chordates originated as a median fusion between the paired dorsal ciliary bands as seen in enteropneust and echinoderm larvae. However, if vertebrates are dorso-ventrally inverted compared with enteropneusts, the larval ciliary bands are on the side corresponding to the ventral side of vertebrates.

\section{Deuterostome origins}

The differences between the protostomian and deuterostomian, or gastroneuralian and notoneuralian, conditions have been taken to indicate a more or less deep cleft between the two designs. In an extreme view, the two lines have been derived independently from coelenterates (for instance, Nielsen 1987). The other extreme claims derivation of the deuterostomes from advanced protostomes. Other trees can be placed between these two extremes, deriving both deuterostomes and "higher" protostomes from either non-coelomate bilaterians, from coelomates with few coelom compartments, or from segmented polymeric coelomates. Some of these alternatives have been illustrated by Salvini-Plawen (1982: Fig. 1). The multitude of alternatives demonstrates the difficulty or even inability to elucidate relationships at the phylum level from the study of comparative anatomy and embryology. The addition of phylogenetic ("cladistic") methods has not changed our inability to understand the phylogenetic significance of phylotypic designs. This is not necessarily because the methods are poor, but because there was an overwhelming evolutionary parallelism between phyla. No formalised method enables us to confidently sort out the order of innovations in an evolutionary pattern dominated by parallelism. All approaches thus suffer from (a) the difficulty to understand the significance of the intermediate construction of tentaculate (or oligomeran) phyla, and (b) the difficulty to imagine what evolutionary intermediates would have looked like. Nielsen's approach does not change this pattern.

Salvini-Plawen (1982) was the first to interpret the morphologies of oligomerous, i.e., tentaculate, animal phyla in terms of paedomorphosis. This was a radical but important step, since the immense morphological and anatomical differences between sessile (oligomerous) and vagile (polymerous and amerous) coelomates became at once understandable as the result of reasonably small genetic shifts. The new adult simply utilised the ciliary feeding of the larva of its ancestor. This made it unnecessary to assume an immense time interval for the transformation of, say, a worm- or mollusc-like ancestor into an oligomerous tentaculated offspring. Furthermore, Salvini-Plawen rightly saw the construction and development of phoronids as in several ways intermediate between "spiralians" and deuterostomes. He also suggested that oligomerous animals share a common ancestry, perhaps closest to the sipunculids, and that echiurids, annelids and arthropods are somewhat further apart.

Bergström (1986), being unaware of the ideas of Salvini-Plawen (1982), tried to understand the morphological and anatomical evolution accepting phylogenetic trees based on molecular evolution. The apparent phylogenetic closeness of animals with radically different body designs asked for a non-conventional interpretation, and - just as in Salvini-Plawen's approach - the mechanism was sought in paedomorphosis. There is one difference, however. Whereas Salvini-Plawen saw the oligomerous/tentaculate condition as being "invented" only once, the distribution of tentaculates in the molecular trees made Bergström believe in a multiple origination of tentaculates. 
When trying to identify the course of evolution, we tend to look for unique events. Their existence is suggested by character similarities between animals and animal groups, and there certainly have been such events. However, more often than not, phylogenetic trees change when characters used for the tree construction are shifted. Obviously this must happen, since many characters are irregularly distributed among phyla, and the distributional irregularity of one character differs from that of virtually all the others. In fact, character distribution forms a mosaic in almost any tree. An attempt to use Nielsen's (1987) character matrix in a students' course for making a phylogenetic tree showed that at least two thirds of the characters have multiple origin and that each shift of trees made other characters polyphyletic. Nielsen's matrix being highly generalised, it is clear that most of the characters we use for tree-making are not homologous. Why, then, should the paedomorphic origination of a tentaculate phylum have happened only once? At least monophyly can not be stated as a fact. Obviously, paedomorphosis at this level should always result in the development of ciliated tentacles, sessility, simplification of the neural system, a simple coelom with one compartment associated with the tentacles, etc. The mere presence of these characters does not prove a synapomorphy. Brachiopods, phoronids, bryozoans, pterobranchs (graptolites), pogonophores and endoprocts are tentaculated phyla, but probably nobody regards their tentacles as a synapomorphy shared by all groups. Endoprocts, for example, are so tiny that they need neither a coelom nor a vascular system. In this case, the tentacles appear to have evolved from the first ring of the larval cilia, whereas they apparently formed from the second ring in other tentaculates (but not in sipunculids, which are similar to endoprocts in this respects but much larger, and therefore cannot rely on ciliary feeding). Pogonophores were once thought to be related to pterobranchs. However, chaetae and the segmented hind part of their body suggest that they are paedomorphic annelids. Also, brachiopods, phoronids, bryozoans and pterobranchs have enough dissimilarities to suggest different origins although molecules indicate a close relationship between brachiopods and phoronids.

In conclusion, it is virtually impossible to reconstruct the origin of deuterostomes on the base of classical comparative anatomy. A comment by Janvier (1996) may illustrate the dilemma: "Early statements about vertebrate origins were generally derived from far-fetched comparisons with molluscs. Lamarck believed that the 'considerable gap' between molluscs and vertebrates would be filled by animals that 'remained to be discovered'. This gap was never filled ...". Maybe it now is. Several molecular trees in fact indicate that molluses are closer to deuterostomes than is any other phylum (Fig. 2). Two centuries of anatomical comparisons had not improved our understanding on this point.

\section{"Calcichordates"}

If deuterostomes stem from soft-bodied ancestors, and deuterostomes such as graptolites (including pterobranchs), enteropneusts and urochordates lack a skeleton, it is easy to imagine that cephalochordates and vertebrates evolved from ancestors devoid of a skeleton. However, an alternative derivation was suggested by T. Gislén (1930), namely from 'carpoids' (now called homalozoans) - an assemblage of extinct skeletonised animals considered as echinoderms by most echinoderm specialists. The idea was later adopted by R. P. S. Jefferies. In recent years he elaborated this hypothesis and also published a short review in French (Jefferies 1987). Recently Gee (1996) gave another review of the hypothesis.

Jefferies' model starts with a pterobranch-like, exteriorly symmetrical, soft-bodied animal. From this, one line would have led to modern hemichordates, another to the other deuterostomes. In the second line, animals reclined on one side and therefore turned asymmetric; they also developed a calcitic mesodermal skeleton. Subsequently, one branch developed radial symmetry and turned into typical echinoderms. The other branch developed a locomotive tail, thereby turning into what Jefferies calls "calcichordates". In the most agile forms, the body evolved into a more symmetrical shape. The more asymmetric forms belong to the order Cornuta, the - superficially - more symmetric ones to the order Mitrata, both of the class Stylophora. According to Jefferies, such skeletonised forms have independently given rise to cephalochordates, urochordates and vertebrates. The stylophorans have a seemingly powerful appendage. Also, there was in his interpretation a surprisingly large (mammal-size!) brain at the boundary between the body and the appendage, from which coarse nerve cords extended along the sides of the body. 


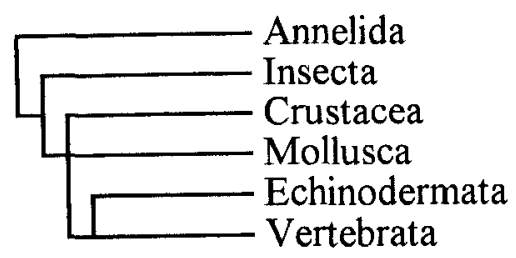

A

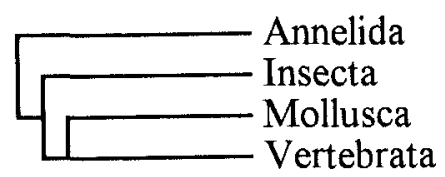

B

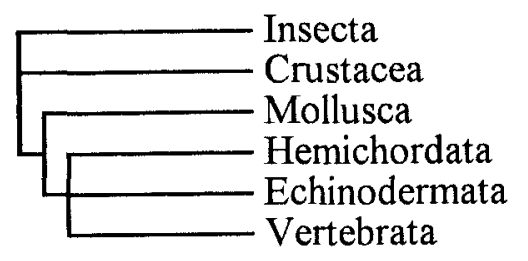

C

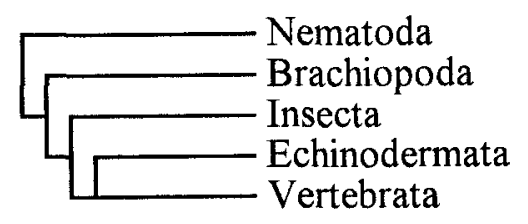

D

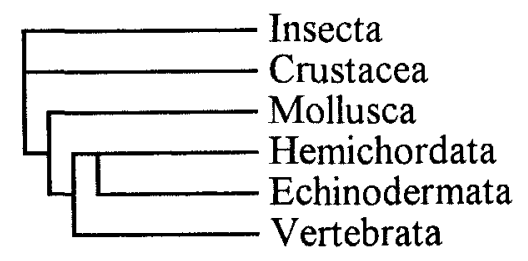

$\mathrm{E}$

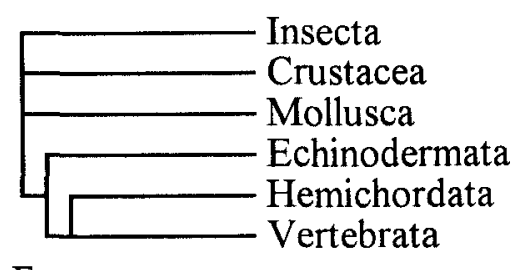

F

Fig. 2. Molecular trees supporting a derivation of "deuterostomes" from protostomes. A, Phylogeny based on cytochrome $c$, mutational noise reduction method (redrawn from Bergström 1986). B, Phylogeny based on 5S rRNA, mutational noise reduction method (redrawn from Bergström 1986) C, Phylogeny based on globin sequences (simplified from Goodman et al. 1988). D, Phylogeny based on 18S rRNA with secondary structure model of Dams et al. (from Winnepenninckx \& Backeljau 1996). E, Phylogeny based on 18S rRNA with secondary structure model of Van de Peer et al. (from Winnepenninckx \& Backeljau 1996). F, Strict consensus tree based on three $18 \mathrm{~S}$ rRNA maximum parsimony trees published by Holland et al, with paired positions excluded (from Winnepenninckx \& Backeljau 1996). Switching part of the tree upside-down may explain a striking difference from certain other published trees (for instance Raff 1995)

\section{Origin of segmented chordates - three alternatives}

The urochordates (or "tunicates") are so specialised that their present morphology is probably an unreliable guide to the organization of the earliest chordates. For an analysis there remain the segmented chordates, that is, the cephalochordates (amphioxus) and vertebrates. These two groups, although dissimilar in many details, share a sufficient number of characters including basic body design to reconstruct the shared ancestor. However, rather than hypothesising, we can also use the amphioxus anatomy for a direct comparison with hemichordate, and particularly enteropneust, anatomy. In the orientation of the animals given by nature, a cross section reveals a striking resemblance (Fig. 1; Bergström 1997: Fig. 3). Thus, gills open upwards, gonads are dorsal and placed in "wings" (not present in all enteropneusts), the main nerve cord is ventral, the stiffening notochord of amphioxus has a counterpart (the pygochord) in the same position in some enteropneusts, the main body musculature is separated into paired ventral blocks, and the direction of blood circulation is identical. It may be added that individual enteropneust species have been seen swimming and apparently feeding directly from the water.

At least three different origins for segmented chordates have been suggested. According to one (Berrill 1955), they arose from sessile urochordates through paedomorphosis. According to Jefferies and his associates (see above), their origin is among so-called calcichordates. Ultimately, a derivation from enteropneust-like animals is supported by the similarities (Bergström 1997) seen when segmented chordates are oriented with the neural side down.

Berrill's and Jefferies' models are both ingenious in their own ways. The main drawback is that they require many more evolutionary steps than a derivation directly from hemichordates and are therefore less parsimonious. This is an important difference, since in all three models, and according to general views, the hemichordates are the least derived deuterostomes. The lack of parsimony is particularly striking in Jefferies' model (Table 1): the enteropneust design has to be deformed and rotated sideways by $90^{\circ}$, a new bilateral symmetry shaped $90^{\circ}$ from the old one, a hard skeleton has to be formed only to be lost again, the tail has to be lost and formed again, and so on until ultimately a body design very close to that present at the start (in 
Table 1. Comparison between the parsimonies in suggested transitions from hemichordates to segmented chordates, via calcichordates (Jefferies), via urochordates (Berrill), or directly (herein)

\begin{tabular}{|c|c|c|c|}
\hline & Jefferies & Berrill & herein \\
\hline loss of vagility in adult & + & + & - \\
\hline secondary vagility in adult & + & + & - \\
\hline adult moves backwards & + & - & - \\
\hline $\begin{array}{l}\text { adult secondarily moves } \\
\text { forwards again }\end{array}$ & + & - & - \\
\hline $\begin{array}{l}\text { loss of hemichordate basic } \\
\text { design }\end{array}$ & + & + & - \\
\hline $\begin{array}{l}\text { restoration of hemichordate } \\
\text { basic design }\end{array}$ & + & + & - \\
\hline formation of calcite skeleton & + & - & - \\
\hline reduction of calcite skeleton & + & - & - \\
\hline $\begin{array}{l}\text { reclining on side, with } \\
\text { asymmetry }\end{array}$ & + & - & - \\
\hline $\begin{array}{l}\text { development of secondary } \\
\text { symmetry }\end{array}$ & + & - & - \\
\hline $\begin{array}{l}\text { loss of one row of gill } \\
\text { openings }\end{array}$ & + & - & - \\
\hline $\begin{array}{l}\text { restoration of one row of } \\
\text { gill openings }\end{array}$ & + & - & - \\
\hline rotation $90^{\circ}$ of vascular system & + & - & - \\
\hline $\begin{array}{l}\text { rotation back } 90^{\circ} \text { of vascular } \\
\text { system }\end{array}$ & + & - & - \\
\hline $\begin{array}{l}\text { removal of gills from mouth } \\
\text { end }\end{array}$ & + & - & - \\
\hline return of gills to mouth end & + & - & - \\
\hline development of gut loop & + & - & - \\
\hline reduction of gut loop & + & - & - \\
\hline loss of tail in adult & + & + & - \\
\hline $\begin{array}{l}\text { development of new tail } \\
\text { in adult }\end{array}$ & + & + & - \\
\hline anus removed from tail & + & - & - \\
\hline $\begin{array}{l}\text { anus moved again to gastral } \\
\text { side }\end{array}$ & + & - & - \\
\hline anus secondarily in tail & + & - & - \\
\hline tail pulling & + & - & - \\
\hline tail pushing & + & - & - \\
\hline tail with dorso-ventral swing & + & - & - \\
\hline tail with lateral swing & + & - & - \\
\hline functional exoskeleton & + & - & - \\
\hline $\begin{array}{l}\text { return to functional endo- } \\
\text { skeleton }\end{array}$ & + & - & - \\
\hline $\begin{array}{l}\text { development of segmen- } \\
\text { tation once }\end{array}$ & + & + & + \\
\hline $\begin{array}{l}\text { segmentation independently } \\
\text { 2nd time }\end{array}$ & + & - & - \\
\hline $\begin{array}{l}\text { somatocoel moved into } \\
\text { tandem position }\end{array}$ & + & - & - \\
\hline $\begin{array}{l}\text { somatocoel returned to pair } \\
\text { position }\end{array}$ & + & - & - \\
\hline Number of steps & 33 & 7 & 1 \\
\hline
\end{tabular}

enteropneusts) is formed again. Jefferies' model of chordate evolution obviously is the least likely of the three discussed here. This reminds us of critique to the same effect raised earlier, for instance by Jollie (1982).

In order not to use Jefferies' phylogenetic arguments on an interpretation of "calcichordates" that he would not accept, his idea of their orientation was followed in the comparison above. However, most specialists on fossil echinoderms consider the calcichordate appendage not as a tail, but as an anterior tentacle. Re-orienting the body would be fatal to Jefferies' interpretation since it is the very orientation that is fundamental to his idea. Yet, such a reorientation has recently received strong support by the recognition of two classes of skeletal elements in echinoderms, the axials and the extraxials (that is, nonaxials or abaxials; Mooi et al. 1994; David \& Mooi 1996). The axials have distinct points of origin close to the mouth and are arranged in rows, usually in pairs. The extraxials form irregularly anywhere outside the axial fields. The axials also extend along the radii of the vascular system and extend into arms, where such exist. In "calcichordates" the skeletal plates of the theca obviously belong to the non-axial class, whereas at least part of the appendage is formed by axials. Therefore the appendage corresponds in this respect to the circum-oral region and oral appendages in other echinoderms - not to the stalk.

\section{Cephalochordates}

The amphioxus has many similarities with vertebrates. One of them is a tendency towards asymmetry. It is important not to interpret this as a similarity to asymmetric echinoderms including so-called calcichordates. What is shared between chordates and echinoderms is the word 'asymmetry' in descriptions, not any factual asymmetry character.

Amphioxus asymmetry is notable by the alternating dispositions of left and right muscle myotomes and their nerves. It is also expressed in the development, during which gill openings first form only on the left side (natural orientation, not conventional), and the mouth on the right side, of the body (e.g., Bergström 1997: Fig. 4). The significance of this phenomenon is unknown. However, there may be some relationship to the development of the notochord in the amphioxus, which extends to the anterior end to support it during burrowing. This extension, being present also in the embryo and larva, makes it impossible for the mouth to form in front of the main ventral nerve cord, where it is located in urochordates, hemichordates and protostomes. It is notable that the mouth of the adult amphioxus is on the anterodorsal side of the head, rather than on the ventral side as in urochordate larvae, hemichordates and many protostomes. This deviation, however, may be an adaptation to filter-feeding, in which only the mouth sticks out of the sediment. 


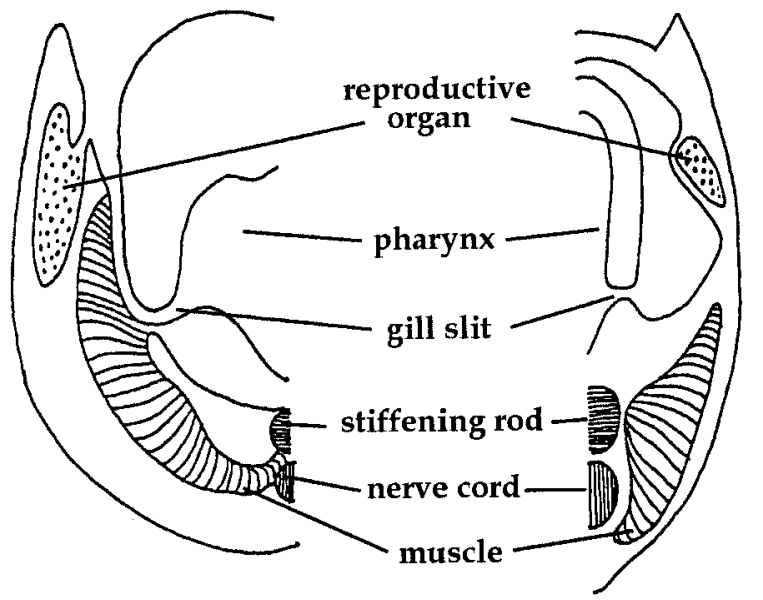

Enteropneust

Amphioxus

Fig. 3. Idealized cross sections of an enteropneust hemichordate and an amphioxus. Note the close correspondance between the two when the amphioxus is not oriented as conventionally but, as in nature, with its "dorsal" side down

Perhaps the asymmetric mouth formation is caused by the development of the notochord. An alternative possibility is that the ancestors of amphioxus animals did not burrow but lived as recliners, with the mouth facing upward when the animals were lying on their left (natural) side. As a third possibility, larval asymmetry may be a functional requirement: before the tail is functional, the larva of Branchiostoma lanceolatum rotates while swimming, which means that it can collect food from all around its body when feeding. This behaviour is analogous to the rotational swimming in larvae of molluscs, annelids and enteropneusts. However, the larvae of Branchiostoma floridae are reported not to rotate while feeding (Gilmore 1996; Stokes 1997) and still have the asymmetry.

Although the mouth of Branchiostoma embryos forms in an unconventional position, it seems unlikely that it is not formed out of the old one. Anyway, it does develop in a new place (Fig. 4), and moves virtually to the dorsal side in the adult. So it is anatomically justified to use the term 'deuterostome' for the amphioxus. This is in contrast to urochordates and hemichordates, where the mouth apparently develops in the same place as in protostomes. Apart from the amphioxus, only the vertebrates are true 'deuterostomes' in the sense that they have their mouth on the side that was originally the dorsal one (Bergström 1997). However, while the amphioxuses have retained their original dorsoventral orientation, so being functionally 'gastroneuralians', the vertebrates are turned over, to become the only functional 'notoneuralians' among all animals.

It is generally taken for granted that segmentation in amphioxus and vertebrates originated as an adaptation to swimming. However, this is by no means certain. Amphioxus could probably live without swimming in the adult stage and the most important function of its segmented musculature seems to be burrowing. Given the right medium, this process is extremely fast, and it is clear that this efficiency has to do with the powerful musculature. Burrowing lasts no more than a few seconds at the most, and this appears to be the maximum time also for flashes of a fast type of swimming. Actually, amphioxus swimming may be considered as a kind of burrowing performed in water. The repetition of neural nodes and muscle cells in appendiculariaceans such as Oikopleura is sometimes compared with

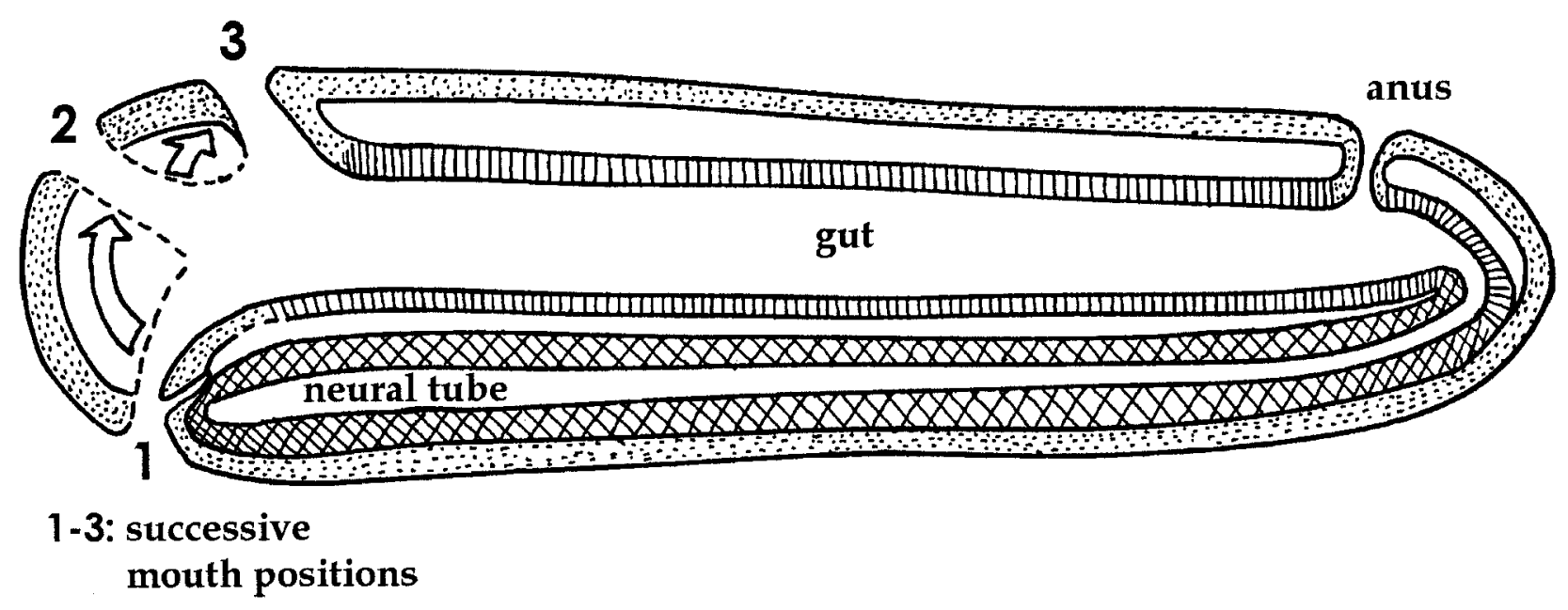

Fig. 4. Generalised chordate embryo, with arrows showing the shift in mouth position from urochordates to vertebrates. With the position acquired in vertebrates, the body has turned over so that the nerve cord became dorsal 
segmentation (polymery), but is probably better referred to as pseudosegmentation (pseudomery), that is, repetition of organs rather than of body packages, a logical pre-segmentation stage.

\section{Conodonts and other early supposed and real deuterostomes}

Amphioxus has remained primitive in one important respect: its way of feeding. It still uses the ciliary feeding characteristic for both hemichordates and urochordates. In vertebrates, such a mode of feeding is known only from larval lampreys, where it goes along with a semi-sessile life style. The distinguishing character of vertebrates is that they search their food actively with the aid of sense organs situated in the head. Therefore eyes form an integral part of the basic vertebrate design. Accordingly it should be possible to use the presence or absence of eyes to distinguish early lancelets from early non-skeletonised members of the vertebrate lineage.
Here the conodont animal comes into the picture. Its teeth cannot be homologised with vertebrate hard tissues (Schultze 1996). The same can, of course, be said about modern cyclostome teeth and is thus no argument against a relationship with vertebrates. The soft parts of the conodont animal are now better known and give a more conclusive answer to our questions. Purnell (1995) conveniently summarised the present knowledge of the soft parts. It is now clear that conodonts had a fish-like appearance, including a tail fin. The musculature was divided into $\mathrm{V}$ shaped myomeres, a character exclusively shared by lancelets and vertebrates. The teeth worked laterally rather than vertically. This shows that the conodont animals were not gnathostomes. Nevertheless, the mere presence of teeth as well as well-developed lateral eyes (or ears, as suggested by Pridmore et al. 1997) shows that the conodont animals were already on the vertebrate side of the divide between vertebrates and lancelets. There is no evidence of any hard skeleton, but there was probably a thick notochord (Al-

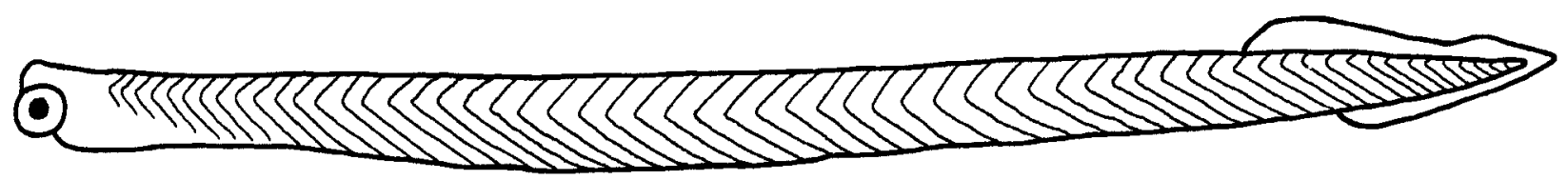

\section{A Conodont}

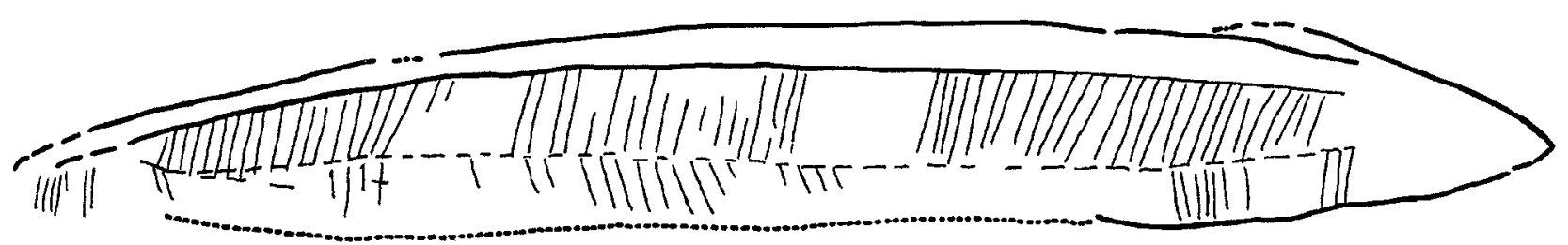

\section{B Pikaia}

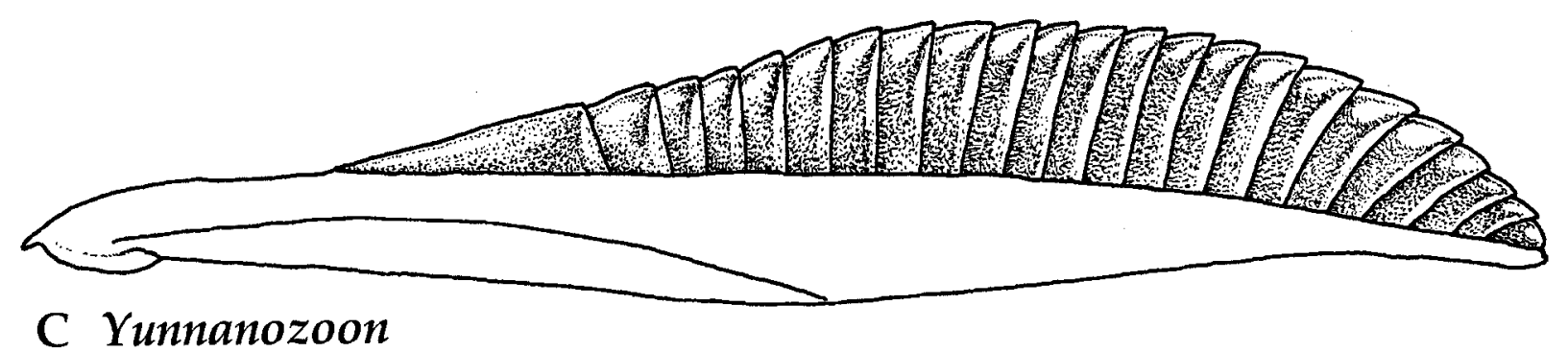

Fig. 5. A. Clydagnathus windsorensis, a conodont animal from the Carboniferous of Scotland (from Bergström 1997). B. Pikaia gracilens, a possible amphioxus relative from the Middle Cambrian Burgess Shale (from Bergström 1997). C. Yunnanozoon lividum, a worm-like animal from the Lower Cambrian Chengjiang fauna, supposed by some authors to be either a chordate or a hemichordate. Claimed muscle segments are here interpreted as hard, overlapping sclerites in the skin. A ventral area behind the mouth is supported by a flexible but strong dermal sheath. (New drawing. All three species about 4 cm long.) 
dridge \& Purnell 1996, Fig. 3), whose lack of vertebrae might cause a dispute whether or not conodont animals should be called vertebrates. However, this is of no interest or consequence for our understanding of conodont animals as being early representatives of the vertebrate lineage which represents a sister group of the amphioxus lineage. There will also be a discussion on whether or not the Early and Middle Cambrian conodont-like teeth really belonged to relatives of the later conodont animals.

The report of sensory organs for orientation (eyes or perhaps ears) in conodont animals is really important news. Much more dubious are other claimed chordates (Fig. 5). One of them is the Burgess Shale (Middle Cambrian) Pikaia gracilens. Its median fins and $\mathrm{V}$-shaped myomeres make it a chordate, but there is no evidence of either eyes or teeth. If this absence is real, Pikaia may be a relative of the modern amphioxus. Its size and shape possibly indicates that it was not a burrower, but may have been swimming or reclining on its side on the bottom. Anyway, the clayey sediment in which it is preserved could not have been suitable for burrowing.

Reinterpretations of Yunnanozoon from the Lower Cambrian Chengjiang Lagerstätte have

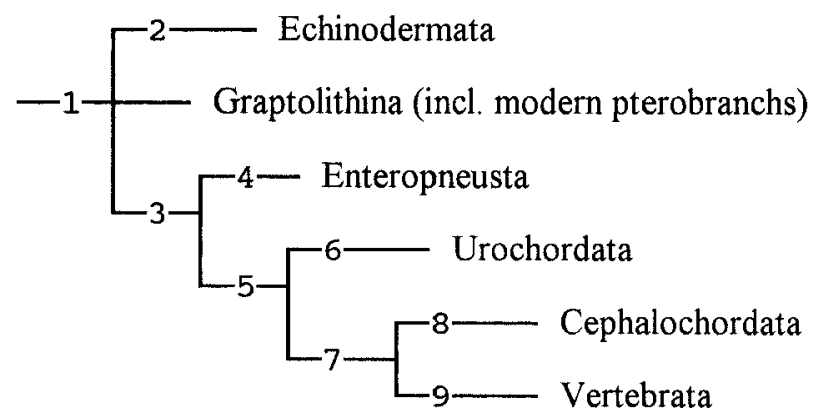

Fig. 6. Suggested cladogram of deuterostomian phyla. 1, origination of the Graptolithina (and Deuterostomia as a whole): paedomorphic retension of ciliary feeding and development of tentacles, development of pharyngeal slits as water outlets; three coelomic compartments, and hydropore, development of tube, and U-shaped gut; 2, detachment from tube, reclining with initial asymmetry, calcite endoskeleton; $\mathbf{3}$, detachment from tube, burrowing with the use of proboscis, and straightening of gut; $\mathbf{4}$, no major change; 5 , swimming with development of notochord (from enteropneust pygochord?) and tail, loss of proboscis and hydropore, developmental modification of blastopore closure resulting in tubeshaped neural cord; $\mathbf{6}$, simplification, loss of constant direction of blood flow, loss of coelom, strong development of cuticle and loss of external ciliation; 7, development of powerful segmented muscles for new burrowing habits, segmentation affecting 3rd coelom pair, shift of mouth to dorsal side; 8 , improvement of adaptation; 9, loss of ciliary feeding, development of sensory organs including eyes with adoption of active search for food, rotation to upside-down posture to keep mouth below eyes. recently been published (Chen et al. 1995; Dzik 1995). Since repeated dark bands were interpreted as segmental myomeres, the animal was regarded as a chordate. However, in contrast to the segmental muscle blocks of segmented chordates these bands are not V-shaped (Fig. 5). Furthermore, the bands overlap one another, which suggests that they are not muscle blocks, but hard sclerites in the skin. Also, the rows of supposed internal gill slits (or branchial archs) are not simply transverse to the gut, but shift from being more or less transverse to more or less longitudinal, and from being straight to strongly curved. This variability is extremely difficult to account for if the slits were connected with dorso-ventral rows of penetrations of the pharynx wall. Whatever Yunnanozoon may be, it has nothing to do with chordates (or hemichordates; cf. Hou et al. 1991, pp. 408-409).

Also from the Chengjiang fauna Shu et al. (1996) described a single, poorly preserved, specimen of Cathaymyrus diadexus and interpreted it as a cephalochordate. This is possible, but since no fins are preserved and the interpretation of the alimentary canal, notochord, pharynx, gill slits, and myomeres must be corroborated by more and better material, it is not yet possible to make any reasonable judgement on the systematic position or importance of this species.

\section{Deuterostome phylogeny}

As a result of the considerations, the phylogeny of the deuterostomes can be summarised as in Fig. 6. It is comparatively easy to imagine how both echinoderms and enteropneusts could have evolved from pterobranch-like animals. Chordates are most reasonably derived from enteropneust-like ancestors (cf. Fig. 3). Since in effect only cephalochordates and vertebrates have a secondary position of the mouth, and only the vertebrates are turned upside-down, the other groups may as well be called protostomes or gastroneuralians. This means that there is every reason to believe that they, like other ciliary-feeders, were derived from other protostomes by paedomorphosis. Vertebrates are the only real notoneuralians.

\section{Acknowledgements}

We are grateful Professor Ragnar Olsson for inspiring discussions, to the Marine Biological Station at Kristineberg for logistics, and to the Hierta-Retzius Foundation and the foun- 
dation "Till Bröderna Jacob och Marcus Wallenbergs Minne" for economic support. We are also grateful to the reviewer Professor A. Seilacher for suggesting numerous improvements of our manuscript.

\section{Referencs}

Aldridge, R. A. \& Purnell, M. A. 1996. The conodont controversies. - Tree 11 (11): 463-468.

Arendt, D. \& Nübler-Jung, K. 1994. Inversion of dorsoventral axis? - Nature 371: 26.

Chen Jun-yuan, Dzik, J., Edgecombe, G. D., Ramsköld, L. \& Zhou Gui-qing 1995. A possible Early Cambrian chordate. - Nature 377: 720-722.

Bergström, J. 1986. Metazoan evolution - a new model. Zoologica Scripta 15(3): 189-200

- 1994. Ideas on early animal evolution. In Bengtson, S. Early Life on Earth, pp. 460-466. Columbia University Press, New York.

- 1997. Origin of high-rank groups. - Palaeontological Research 1: $1-14$.

Berrill, N. J. 1955. The Origin of Vertebrates. 237 pp. Clarendon Press, Oxford

David, B. \& Mooi, R. 1996. Embryology supports a new theory of skeletal homologies for the phylum Echinodermata. - Comptes Rendus de l'Academie des Sciences de Paris, Sciences de la vie 319: $577-584$.

De Robertis, E. M. \& Sasai, Y. 1996. A common plan for dorsoventral patterning in Bilateria. - Nature 380: 37-40.

Dzik, J. 1995. Yunnanozoon and the ancestry of chordates. Acta Palaeontologica Polonica 40: $341-360$.

Emlet, R. B. 1994. Body form and patterns of ciliation in nonfeeding larvae of echinoderms: Functional solutions to swimming in the plankton? - American Zoologist 34: $570-585$.

Garstang, W. 1894: Preliminary note on a new theory of the phylogeny of the Chordata. - Zoologische Anzeiger 17: $122-125$.

Gee, H. 1996. Before the Backbone: Views on the Origin of the Vertebrates. 346 pp. Chapman \& Hall.

Gilmore, T. H. J. 1996. Feeding methods of cephalochordate larvae. - Israel Journal of Zoology 42, Supplement: $\mathrm{S} 87-\mathrm{S} 95$.

Gislén, T. 1930. Affinities between the Echinodermata, Enteropneusta, and Chordonia. - Zoologiska Bidrag frăn Uppsala 12: 199-304.

Goodman, M., Pedwaydon, J., Czelusniak, J., Suzuki, T., Gotoh, T., Moens, T., Shishikura, F., Walz, D. \& Vinogradov, S. 1988. An evolutionary tree for invertebrate globin sequences. - Journal of Molecular Evolution 27: 236-249.

Holley, S. A., Jackson, P. D., Sasai, Y., Lu, B., De Robertis, E. M., Hoffmann, F. M. \& Ferguson, E. L. 1995. A conserved system for dorsal-ventral patterning in insects and vertebrates involving sog and chordin. - Nature 376: $249-253$

Hou Xian-guang, Ramsköld, L. \& Bergström, J. 1991. Composition and preservation of the Chengjiang fauna - a Lower Cambrian soft-bodied biota. - Zoologica Scripta 20(4): 395-411.

Janvier, P. 1996. Spineless debates. - Nature 384: 324-325.

Jefferies, R. P. S. 1987. A l'origine des vertébres: les animaux bottines. - La Recherche 18: 1101-1104.

Jollie, M. 1982. What are the 'Calcichordata'? and the larger question of the origin of chordates. - Zoological Journal of the Linnean Society 75: 167-188.

Lacalli, T. C. 1996. Landmarks and subdomains in the larval brain of Branchiostoma. Vertebrate homologs and invertebrate antecedants. - Israel Journal of Zoology 42, Supplement, The Lancelets: A new look at some old beasts: S131-S146.

Mooi, R., David, B. \& Marchand, D. 1994. Echinoderm skeletal homologies: Classical morphology meets modern phylogenetics. In David, B., Guille, A., Féral, N. \& Roux, M. (eds). Echinoderms through Time: 87-95, Balkema, Rotterdam.

Nielsen, C. 1987. Structure and function of metazoan ciliary bands and their phylogenetic significance. - Acta Zoologica 68: 205-262.

Nübler-Jung, K. \& Arendt, D. 1994. Is ventral in insects dorsal in vertebrates? - Roux's Archives Developmental Biology 203: $357-366$.

Pridmore, P. A., Barwick, R. E. \& Nicoll, R. S. 1997. Soft anatomy and the affinities of conodonts. - Lethaia 29: $317-328$.

Purnell, M. A. 1995. Large eyes and vision in conodonts. Lethaia 28: 187-188.

Raff, R. A. 1994. Developmental mechanisms in the evolution of animal form: Origins and evolvability of body plans. In Bengtson, S. Early Life on Earth, pp. 489-500. Columbia University Press, New York.

Salvini-Plawen, L. 1982. A paedomorphic origin of the oligomerous animals? - Zoologica Scripta 11(2): 77-81.

Schultze, H.-P. 1996. Conodont histology: an indicator of vertebrate relationship? - Modern Geology 20: 275-285.

Shu De-gan, Conway Morris, S. \& Zhang Xing-liang. 1996. A Pikaia-like chordate from the Lower Cambrian of China. - Nature 384: 157-158.

St. Hilaire, E. G. 1822. Considérations générales sur la vertèbres. - Mémoires de Muséum Histoire Naturelle 9: 89-119.

Stokes, M. D. 1997. Larval locomotion of the lancelet Branchiostoma floridae. - The Journal of Experimental Biology 200: 1661-1680.

Winnepenninckx, B. \& Backeljau, T. 1996. 18S rRNA alignments derived from different secondary structure models can produce alternative phylogenies. - Journal of Zoological Systematics and Evolutionary Research 34: $135-143$. 